\title{
Purification and Characterization of New Alkaline L-methioninase from Aspergillus ustus AUMC 1051 Grown under Solid-State Fermentation Conditions.
}

\author{
M. A. Abu- Tahon* and G. S. Isaac \\ Department of Biological and Geological Sciences, Faculty of \\ Education, Ain Shams University, Roxy 11757, Cairo, Egypt
}

\begin{abstract}
A LKAline L-methioninase (E.C.4.4.1.11) from Aspergillus $A$ ustus AUMC 1051 was obtained in a good yield amounting to $1321 \mathrm{Uml}^{-1}$ (99.56 $\mathrm{Ug}^{-1}$ bran) under solid state fermentation (SSF) of wheat bran. The enzyme was purified 15.83 -fold with $62.63 \%$ yield after three steps of purification involved ammonium sulfate precipitation, Sephadex G-100 gel filtration and DEAE-cellulose ion exchange chromatography. The purified enzyme had a molecular mass of $46 \mathrm{kDa}$ under denaturating conditions and an isoelectric point of 6 . Maximal activity was recorded at $\mathrm{pH} 8.5$ and $35^{\circ} \mathrm{C}$. Good stability of the purified enzyme was detected over wide $\mathrm{pH}$ values ranging from 8 to 10 and temperature up to $50^{\circ} \mathrm{C}$. The enzyme retained its full activity after 6 days of storage at $4^{\circ} \mathrm{C}$. Four weeks was found the $\mathrm{T}_{1 / 2}$ of its activity. $\mathrm{V}_{\max }$ and $\mathrm{K}_{\mathrm{m}}$, of the purified enzyme were found to be 820 $\mathrm{Uml}^{-1}$ and $1.6 \mathrm{mM}$, respectively. Alkaline L-methioninase activity was stimulated by $\mathrm{Na}^{+}$and $\mathrm{Co}^{+2}$ and strongly inhibited by Hydroxylamine, iodoacetate, $\mathrm{Hg}^{+2}$ and $\mathrm{Cu}^{+2}$. The enzyme was proved to be glycoprotein containing - $\mathrm{SH}$ group in its catalytic site.
\end{abstract}

Keywords: Solid-state fermentation, Alkaline L-methioninase, Purification, Characterization, Aspergillus ustus.

L-methioninase (E.C.4.4.1.11) is a pyridoxal L-phosphate dependent enzyme that catalyzes the deamination and demethiolation of L-methionine to $\alpha$ ketobutyrate, methanethiol and ammonia (Ruiz-Herrera and Starkey, 1969).

The enzyme has received much attention, since it was reported as a potent anticancer agent against various types of tumor cell lines (Tan et al., 1998). Physiologically, normal cells have the ability to grow on homocysteine, instead of methionine, due to their active methionine synthase (Mecham et al., 1983). Unlike normal cells, tumor cells devoid of active methionine synthase thus depend on external methionine supplementation from the diet (Hoffman, 1984). Methionine-dependency was reported as a physiological character for colon, kidney, prostate, melanoma, and fibrosarcoma tumor cells (Miki et al., 2000 and Yamamoto et al., 2003).

* Corresponding author, E-mail: medhatahon@gmail.com 
L-Methioninase has been purified and characterized from various bacterial species including Pseudomonas putida (Tanaka et al., 1977), Aeromonas sp. (Tanaka et al., 1985), Citrobacter freundii (Manukhov et al., 2005), Brevibacterium linens (Amarita et al., 2004), Lactococcus lactis (MartinezCuesta et al., 2006), and Clostridium sporogenes (Krishnaveni et al., 2009). Also, the enzyme was purified from Arabidopsis thaliana (Rebeille et al., 2006). Despite the low therapeutic efficiency of bacterial L-methioninase, due to a high immunogenicity and rapid plasma clearance (Kudou et al., 2007), the purified enzyme has not been comprehensively characterized from a fungal source as far the authors are aware.

\section{Material and Methods}

\section{Fungal strain and growth conditions}

Aspergillus ustus AUMC 10151 was selected as the most potent fungus for production of L- alkaline methioninase from our preliminary studies (Abu-Tahon and Isaac, 2016). A. ustus was grown on the optimized solid state fermentation medium utilizing wheat bran as carbon and nitrogen sources. Maximum alkaline L-methioninase was achieved at initial moisture content of $71.5 \%$, inoculum size of $2 \mathrm{~mL}$ of spore suspension, initial $\mathrm{pH} 8.5$, incubation period 8 days at $30^{\circ} \mathrm{C}$ and supplementation of the salt basal medium with pyridoxine $(100 \mu \mathrm{g} / \mathrm{ml})$ and beet molasses $(20 \%, \mathrm{v} / \mathrm{v})$.

\section{Extraction of alkaline L-methioninase}

At the end of the incubation period, the content of each flask was thoroughly mixed with $40 \mathrm{ml}$ of $0.2 \mathrm{M}$ Glycine- $\mathrm{NaOH}$ buffer ( $\mathrm{pH} 8.5$ ) using a rotary shaker at $200 \mathrm{rpm}$ for $30 \mathrm{~min}$. The whole content of each flask was filtered through muslin cloth and the pooled filtrate was centrifuged at $4000 \mathrm{rpm}$ for $15 \mathrm{~min}$. at 4.0 ${ }^{\circ} \mathrm{C}$. The clear supernatant was collected as the crude enzyme preparation.

\section{Materials}

Nessler's reagent, Folin reagent, pyridoxine, Sephadex G-100 and diethyl amino ethyl cellulose (DEAE-cellulose) were obtained from Sigma-Aldrich (St. Louis, Mo).

\section{L-methioninase assay}

The activity of alkaline L-methioninase was determined using Nessler's reagent (Thomposon and Morrison, 1951) with some modification as follow: $1 \mathrm{ml}$ of the enzyme preparation was incubated with $1 \mathrm{ml}$ of $1 \% \mathrm{~L}$-methionine in $0.2 \mathrm{M}$ Glycine-NaOH buffer $(\mathrm{pH} 8.5)$ and $0.1 \mathrm{ml}$ of pyridoxal phosphate, for $1 \mathrm{hr}$ at $30{ }^{\circ} \mathrm{C}$. The enzyme activity was stopped by adding $0.5 \mathrm{ml}$ of $1.5 \mathrm{~N}$ trichloroacetic acid, followed by centrifugation at $5000 \mathrm{rpm}$ for $5 \mathrm{~min}$. The released ammonia was determined using $0.5 \mathrm{ml}$ Nessler's reagent; the developed color was measured at $480 \mathrm{~nm}$. Enzyme and substrate blanks were used. One unit of L-methioninase was defined as the amount of enzyme that liberates one $\mu$ mole of ammonia/h under optimal assay conditions. Specific activity of Lmethioninase was expressed as the activity of enzyme in term of units per milligram of protein. 


\section{Protein Determination}

The method used was described by Lowry et al. (1951) using bovine serum albumin as the standard.

\section{Enzyme purification}

Enzyme purification was started with dialysing $200 \mathrm{ml}$ of crude enzyme preparation (CEP) of A. ustus overnight against $0.2 \mathrm{M}$ Glycine- $\mathrm{NaOH}$ buffer (pH $8.5)$ at $4^{\circ} \mathrm{C}$. The enzyme was precipitated from the cell-free dialysate (CFD) by gradual addition of $\left(\mathrm{NH}_{4}\right)_{2} \mathrm{SO}_{4}$ using the range of saturation from 50 to $90 \%$. The precipitate was collected by centrifugation, dissolved in minimal of the same buffer, applied to a Sephadex G-100 gel filtration column $(1.5 \times 4.5 \mathrm{~cm})$ and eluted with the same buffer. The fractions possessing the highest L-methioninase activity were collected, pooled, concentrated and applied to ion-exchange chromatography column containing diethyl amino ethyl cellulose (DEAEcellulose). Elution in this case was achieved by a linear gradient of $\mathrm{NaCl}$ up to $0.5 \mathrm{M}$. The fractions containing the highest activity of the purified enzyme were collected, desalted by dialysis, lyophilized by Labconco Freeze Dryer at $-65^{\circ} \mathrm{C}$ and $250 \mu$ bars and stored at $0^{\circ} \mathrm{C}$ for further investigations.

\section{Sodium Dodecyl Sulfate-Polyacrylamide Gel Electrophoresis}

SDS-PAGE was carried out according to Laemmli (1970), using 10\% polyacrylamide. Proteins were detected by Coomassie Brilliant Blue R250 staining.

\section{The isoelectric point for L-methioninase pI}

The isoelectric point for L-methioninase was determined as described by Kantardjieff and Rupp (2004) with slight modifications. The enzyme preparation was incubated at different pHs (5.0-7.0) using potassium phosphate buffer at $4^{\circ} \mathrm{C}$. After $12 \mathrm{hr}$ of incubation, the enzyme was precipitated by centrifugation at $10,000 \mathrm{rpm}$ for $10 \mathrm{~min}$. and the precipitated protein was measured quantitatively using Folin reagent. The isoelectric point was expressed as the $\mathrm{pH}$ range at which the maximum enzyme precipitation occurred.

\section{Determination of kinetic parameters}

The optimum $\mathrm{pH}$ of the enzyme activity was investigated by measurements at $30{ }^{\circ} \mathrm{C}$ in different buffers covering the $\mathrm{pH}$ range of 6-11. These buffer solutions were $0.1 \mathrm{M}$ Citrate-phosphate, $\mathrm{pH}$ 6.0-8.0 and 0.2 M Glycine- $\mathrm{NaOH}$, $\mathrm{pH}$ 8.5-11.0. The $\mathrm{pH}$ stability of the enzyme was determined by measuring its residual activity after incubation for different periods in the buffers with different $\mathrm{pH}$ values. Optimum temperature of the enzyme activity was determined by incubating enzyme at various temperatures ranging from 20 to $60^{\circ} \mathrm{C}$ in $0.2 \mathrm{M}$ Glycine- $\mathrm{NaOH}(\mathrm{pH} 8.5)$. Thermostability of the enzyme was measured after incubating the enzyme at different temperatures for different periods in the same buffer. Enzyme was incubated with various concentrations of L-methionine in $0.2 \mathrm{M}$ Glycine- $\mathrm{NaOH}(\mathrm{pH} 8.5)$ at $35^{\circ} \mathrm{C}$ and different kinetic parameters were calculated. Michaelis constant $(\mathrm{Km})$ and maximum velocity

Egypt. J. Bot., Vol. 56, No. 3 (2016) 
$\left(\mathrm{V}_{\max }\right)$ of enzyme activity were calculated by linear regression from LineweaverBurk plot (Lineweaver and Burk, 1934). Effect of various metal ions and inhibitors on activity of the purified alkaline L-methioninase was assessed by following the standard assay conditions at 1 and $10 \mathrm{mM}$ final concentration.

Substrate Specificity of Purified L-Methioninase.

This experiment was designed to evaluate the specificity of the purified alkaline L-methioninase towards various substrates, namely, L-methionine, Laspargine, L- aspartic acid, L-glutamine, L-glutamic acid, L-lysine and urea. Enzyme activity was assessed by the nesslerization method as described above.

\section{Statistical Analysis}

The obtained data were statistically analyzed with SPSS (Scientific Package for Scientific Social Studies, version 20), in which the equations of the hypothesis tests, including the mean, standard deviation, T-statistics value and probabilities (p) were used.

\section{Results and Discussion}

Purification

A summary of purification procedure for the produced enzyme was presented in Table 1. The results reveal that dialysis of the CEP resulted in reduction of the enzyme activity which can be attributed to the loss of certain metallic ions as stated by Ghareib and Abu-Tahon (2013). Precipitation of proteins from the CFD with $70 \%$ saturation of ammonium sulfate provided a fraction containing the highest enzyme preparation. The same precipitating agent was previously found convenient for maximal precipitation of L-methioninase from A. flavipes (El-Sayed, 2009 and 2011). Completion of enzyme purification was achieved by gel filtration through SephadexG-100 and ion-exchange chromatography with DEAE-cellulose. The present study showed that A. ustus has produced L-methioninase with purification of 15.83 -fold and yield of $62.63 \%$ which is better compared to A. flavipes which has shown 12.1 fold purity with $39.8 \%$ yield (El-Sayed, 2011).

TABLE 1. Purification profile of L-methioninase of Aspergillus ustus AUMC 1051

\begin{tabular}{|l|c|c|c|c|c|}
\hline \multicolumn{1}{|c|}{$\begin{array}{c}\text { Purification } \\
\text { step }\end{array}$} & $\begin{array}{c}\text { Total } \\
\text { activity } \\
\text { (U) }\end{array}$ & $\begin{array}{c}\text { Total } \\
\text { protein } \\
\text { (mg) }\end{array}$ & $\begin{array}{c}\text { Specific } \\
\text { activity } \\
\text { (U/mg } \\
\text { protein) }\end{array}$ & $\begin{array}{c}\text { Yield } \\
(\%)\end{array}$ & $\begin{array}{c}\text { Purificati } \\
\text { on fold }\end{array}$ \\
\hline CEP (200 ml) & 264200 & 2654 & 99.56 & 100 & 1.0 \\
CFD & 242973 & 2654 & 91.55 & 91.97 & 0.91 \\
Ammonium & 220350 & 1180 & 186.73 & 83.40 & 1.90 \\
sulphate (70\%) & 190645 & 550 & 346.62 & 72.15 & 3.50 \\
Sephadex G-100 & 165479 & 105 & 1575.99 & 62.631 & 15.83 \\
\hline DEAE-cellulose & 1650 \\
\hline
\end{tabular}

Egypt. J. Bot., Vol. 56, No. 3 (2016) 


\section{Sodium Dodecyl Sulfate-Polyacrylamide Gel Electrophoresis}

Figure 1 shows the electrophoretogram of the purified alkaline Lmethioninase from A. ustus as determined using SDS-PAGE. The molecular weight of the purified enzyme was estimated after final stage of purification to be $46 \mathrm{kDa}$. The appearance of L-methionine as a single band ensures the homogeneity and purity of the enzyme. Coincident with our results, the molecular weight of the purified L-methioninase produced by various bacterial (Nakayama et al., 1984; Dias and Weimer, 1998 and Takakura et al., 2006), protozoal (Tokoro et al., 2003) and fungal species (El-Sayed, 2009 and Selim et al., 2015) was in the range of 44 to $48 \mathrm{kDa}$.

\section{The isoelectric point for L-methioninase}

The $p I$ for the purified A. ustus L-methioninase was close to 6, which is consistent with that reported for the enzyme from E. histolytica (Tokoro et al., 2003). Meanwhile, the $p I$ s of L- methioninase from C. sporogenes (Kreis and Hession, 1973) and A.flavipes (El-Sayed, 2011) were found to be 4.2 and 5.8, respectively. Having the $p I$ of the purified enzyme far from the normal blood $\mathrm{pH}$ (i.e. 7.4) may suggest a possible application in tumor therapy.

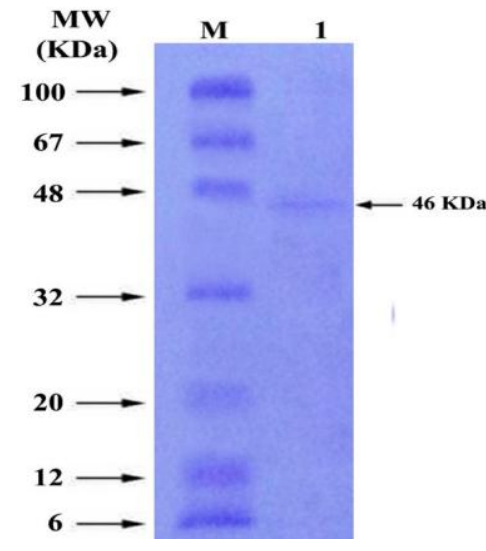

Fig. 1. SDS-PAGE analysis of the purified L-methioninase by A. ustus AUMC 1051. Lane 1, L- methioninase sample. Lane M, molecular weight standards (Marker).

Effect of $\mathrm{pH}$ on enzyme activity and stability

The results (Fig. 2) reveal that the purified enzyme showed a great activity at $\mathrm{pH}$ 8-9.5 with the maximum at $\mathrm{pH} 8.5$. These results are in agreement with the previous findings on other L-methioninase from Clostridium sporogenes (Kreis and Hession, 1973), Cladosporium cladosporioides (Abu-Seidah and Youssef, 2000) and A. flavipes (El-Sayed, 2009). While, our results are in disagreement with that obtained from Candida tropicalis (Selim et al., 2015).

Egypt. J. Bot., Vol. 56, No. 3 (2016) 


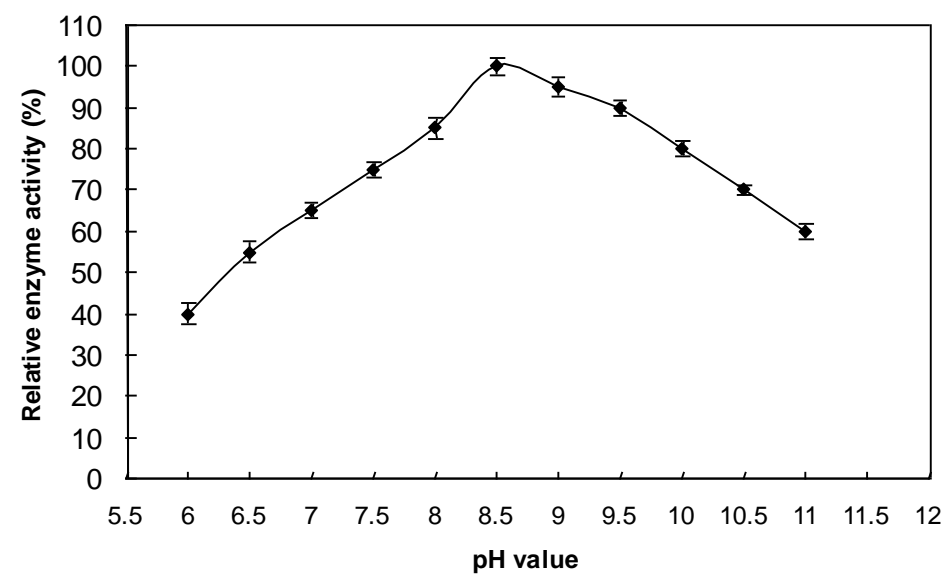

Fig. 2. Effect of pH value on activity of the purified alkaline L-methioninase of $\boldsymbol{A}$. ustus.

The enzyme had a good stability on the alkaline side. It retained full activity after 30 min of incubation at $\mathrm{pH} 8.5$ and about $85 \%$ of the original activity was restored at $\mathrm{pH} 9$ (Fig. 3). After an hour at $\mathrm{pH} 8.590 \%$ of the original activity was recorded. Similar results are obtained by Ruiz-Herrera and Starkey (1969) and El- Sayed (2009).

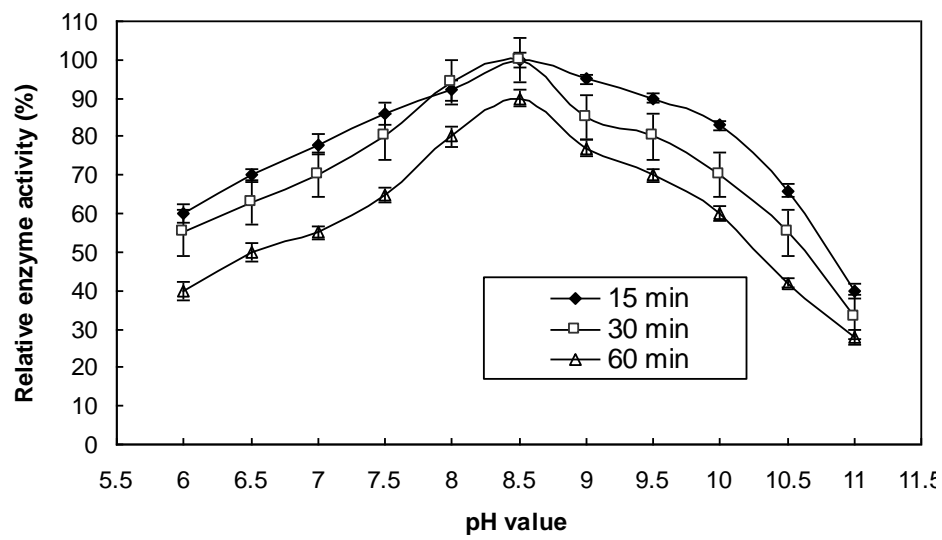

Fig. 3. Effect of $\mathrm{pH}$ value on stability of the purified alkaline L-methioninase of $A$. ustus.

Effect of temperature on enzyme activity and stability

Optimum activity of $A$. ustus alkaline L-methioninase in its purified state was recorded at $35^{\circ} \mathrm{C}$ (Fig. 4). At higher temperatures, a gradual decrease in enzyme activity was observed. This outcome may be explained by the fact that the temperature increases the reaction velocity and also affects the rate of enzyme destruction, producing a gradual fall in the concentration of active enzyme. Our Egypt. J. Bot., Vol. 56, No. 3 (2016) 
results were in complete accordance with that recorded for the enzyme of Aspergillus sp. by Ruiz-Herrera and Starkey (1969) and El- Sayed (2009). Other temperature optima were recorded for purified L-methioninase from other organisms. These were $30^{\circ} \mathrm{C}$ for the enzyme from C. cladosporioides (AbuSeidah and Youssef, 2000) and Citrobacter freundii (Manukhov et al., 2005) and $37^{\circ} \mathrm{C}$ for that from Entamoeba histolytica (Sato et al., 2008). The inactivation of the enzyme at higher temperature may be attributed to the thermal denaturation of the enzyme subunits (Dias and Weimer, 1998).

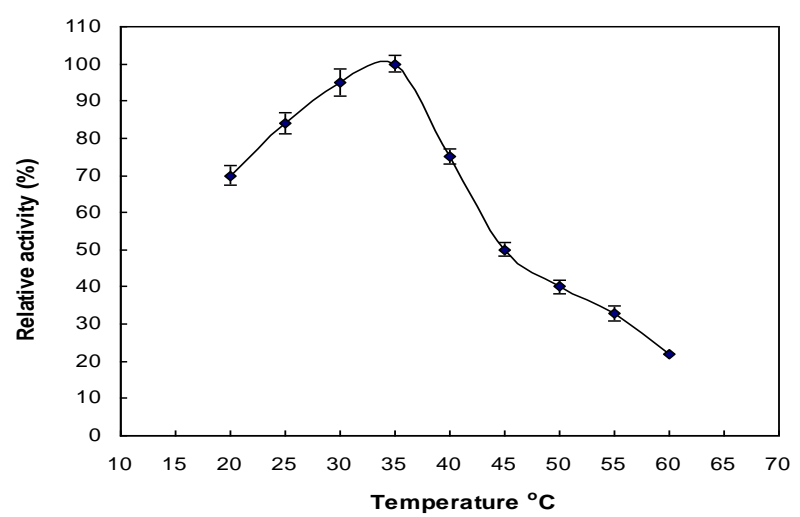

Fig. 4. Effect of temperature on activity of the purified alkaline L-methioninase of $A$. ustus.

The thermostability of the purified enzyme (Fig. 5) was proved as it could tolerate up to $45^{\circ} \mathrm{C}$ for an hour without loss of more than $25 \%$ of its initial activity. It also retained about $55 \%$ of this activity at $50^{\circ} \mathrm{C}$ and $35 \%$ at $60^{\circ} \mathrm{C}$ after heating for complete hour. These results reveal that this enzyme from A. ustus was less thermostable than those of Candida tropicalis (Selim et al., 2015) but more stable than that of A. flavipes (El-Sayed, 2011).

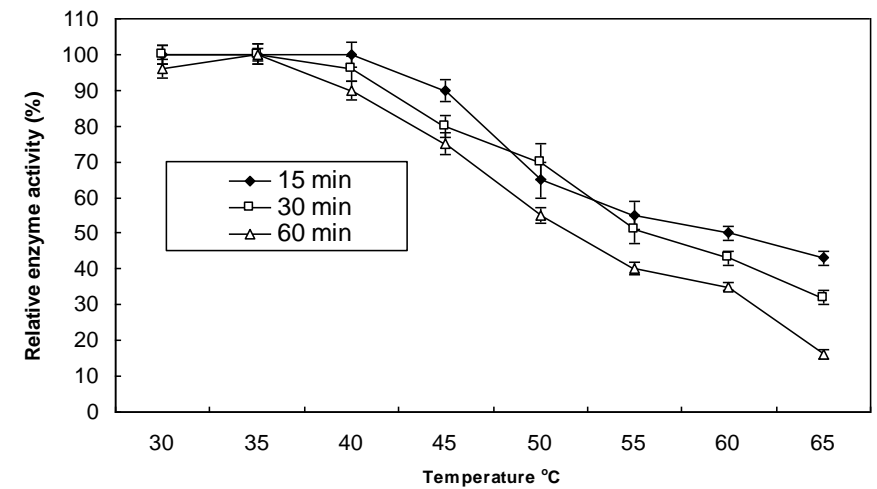

Fig. 5. Effect of temperature on stability of the purified alkaline $L$-methioninase of $A$. ustus .

Egypt. J. Bot., Vol. 56, No. 3 (2016) 
The purified enzyme preparation was found stable for six days when stored at $4^{\circ} \mathrm{C}$. T $1 / 2$ of enzyme activity was found to be four weeks.

\section{Substrate Specificity of Purified L-Methioninase}

Substrate specificity of $A$. ustus L-methioninase revealed that the enzyme had a relative activity towards various amino acids. In Fig. 6 It was found that the enzyme showed the highest affinity towards L-methionine as a standard substrate. The enzyme activities towards L-asparagine and L-glutamine were $58 \%$ and $50 \%$, respectively. While the enzyme activity towards the other substrates were less than 20\%. Our results are agreed with EL-Sayed (2011) who reported that the L-methioninase purified from A. flavipes had relative catalytic activity towards the same investigated amino acids.

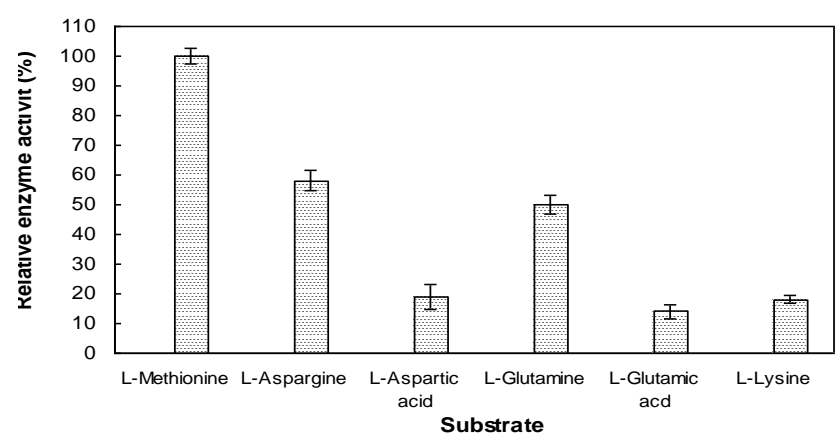

Fig. 6. Substrate specificity of purified L-methioninase determination of kinetic parameters.

\section{Catalytic properties}

$\mathrm{V}_{\max }$ of purified enzyme was calculated to be $820 \mathrm{Uml}^{-1}$ (Fig. 7). Km value was calculated from the Lineweaver-Burk plot of reciprocals of initial velocities and substrate concentrations to be $1.6 \mathrm{mmol}$ (Fig. 8). This value is very near from that recorded for the same enzyme from pseudomonas putida (Takakura et al., 2004).

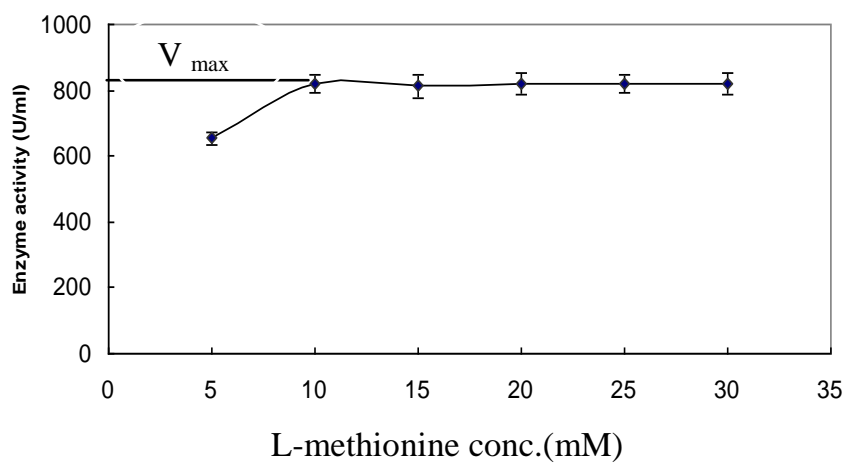

Fig. 7. Effect of L-methionine concentration on activity of the purified alkaline Lmethioninase of $A$. ustus.

Egypt. J. Bot., Vol. 56, No. 3 (2016) 


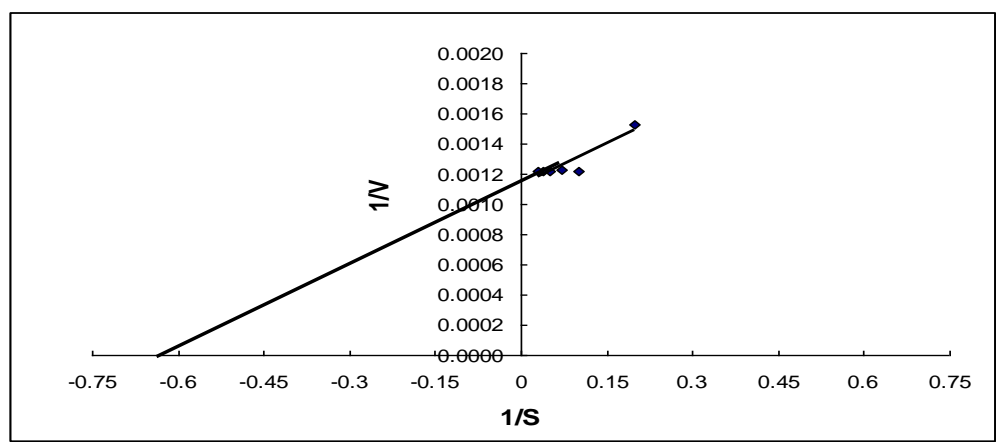

Fig. 8. Lineweaver-Burk plot of the reciprocal of initial velocities and L-methionine concentrations.

\section{Effect of Different Metal Ions and Inhibitors on L-Methioninase activity}

Metal ions may serve as activators or inhibitors in numerous enzymatically catalyzed reactions. Therefore, the effect of some metal ions on alkaline Lmethioninase activity was investigated (Table 2). The results showed that $\mathrm{Na}^{+}$ and $\mathrm{Co}^{+2}$ act as potent activators, where the enzyme activity was significantly of the enzyme from autoproteolysis and thermal denaturation (Secades increased to 120 and $115 \%$, respectively, of the original activity at a final concentration of 10 mM. Moreover, $\mathrm{Ca}^{+2}, \mathrm{Mg}^{+2}$ and $\mathrm{Ni}^{+2}$ had slightly stimulatory effect on enzyme activity. On the other hand, the enzyme activity was inhibited in the presence of $\mathrm{Cu}^{+2}, \mathrm{Zn}^{+2}, \mathrm{Hg}^{+2}$ and $\mathrm{Fe}^{+2}$. These results are in consistent with that reported for fungal L-methioninase (Abu-Seidah and Youssef, 2000, El-Sayed, 2009 and Selim et al., 2015). Generally, the stimulatory effect of metal ions may be ascribed to their stabilizing effect to the conformational structure, protection and Guijarro, 2001).

Presence of all enzyme inhibitors affected unfavorably its activity. The largest inactivation was recorded in presence of carbonyl reagents such as Hydroxylamine which is strongly inhibitor to the pyridoxal 5-phosphate insuring the pyridoxal dependence of this enzyme (Dias and Weimer, 1998). The enzyme was completely inactivated by a thiol reducing agent such as iodoacetate which react with sulfur amino acids (Lockwood and Coomps, 1991). The complete inhibition of L-methioninase with this agent provides evidence for the presence of $-\mathrm{SH}$ group in the active sites of enzyme. 
TAPLE 2. Effect of some chemical components (metal ions and enzyme inhibitors) on activity of the purified alkaline L-methioninase.

\begin{tabular}{|c|c|c|}
\hline Components* & $\begin{array}{l}\text { Conc. } \\
(\mathbf{m M})\end{array}$ & Relative enzyme activity (\%) \\
\hline Control & 0.0 & 100 \\
\hline \multicolumn{3}{|l|}{ Metal ions } \\
\hline \multirow{2}{*}{$\mathrm{K}^{+}$} & 1 & 100 \\
\hline & 10 & 96 \\
\hline \multirow{2}{*}{$\mathrm{Na}^{+}$} & 1 & 100 \\
\hline & 10 & 120 \\
\hline \multirow{2}{*}{$\mathrm{Ca}^{+2}$} & 1 & 100 \\
\hline & 10 & 104 \\
\hline \multirow{2}{*}{$\mathrm{Co}^{+2}$} & 1 & 105 \\
\hline & 10 & 115 \\
\hline \multirow{2}{*}{$\mathrm{Cu}^{+2}$} & 1 & 82 \\
\hline & 10 & 44 \\
\hline $\mathrm{Mg}^{+2}$ & 1 & 100 \\
\hline \multirow{2}{*}{$\mathrm{Zn}^{+2}$} & $\begin{array}{c}10 \\
1\end{array}$ & $\begin{array}{c}102 \\
95\end{array}$ \\
\hline & 10 & 72 \\
\hline \multirow{2}{*}{$\mathrm{Hg}^{+2}$} & 1 & 82 \\
\hline & 10 & 44 \\
\hline \multirow{2}{*}{$\mathrm{Fe}^{+2}$} & 1 & 80 \\
\hline & 10 & 52 \\
\hline \multirow{2}{*}{$\mathrm{Ni}^{+2}$} & 1 & 100 \\
\hline & 10 & 107 \\
\hline \multicolumn{3}{|l|}{ Enzyme inhibitors } \\
\hline \multirow{2}{*}{ SDS } & 1 & 84 \\
\hline & 10 & 60 \\
\hline \multirow{2}{*}{ Hydroxylamine } & 1 & 15 \\
\hline & 10 & 5 \\
\hline \multirow{2}{*}{ EDTA } & 1 & 94 \\
\hline & 10 & 86 \\
\hline \multirow{2}{*}{ PMSF } & 1 & 25 \\
\hline & 10 & 55 \\
\hline \multirow[t]{2}{*}{ Iodoacetate } & 1 & 44 \\
\hline & 10 & 23 \\
\hline
\end{tabular}

*The enzyme was pre-incubated with these components (metal ions were added as chlorides) for 15 minutes at the two indicated concentrations.

\section{References}

Abu-Seidah, A.A., and Youssef, M.S. (2000) Characterization of L-methionine g-lyase from Cladosporium cladosporioides. Bull. Fac. Sci. Assiut Univ. Egypt, 130, 83-91. 
Abu-Tahon, M.A and Isaac, G.S (2016) Comparative study of a new alkaline Lmethioninase production by Aspergillus ustus AUMC 10151 in submerged and solidstate fermentation. Braz. Arch. Biol. Technol, 59, 1-10.

Amarita, F., Yvon, M., Nardi, M., Chambellon, E., Delettre, J. and Bonnarme, P. (2004) Identification and functional analysis of the gene encoding methionine- $\gamma$-lyase in Brevibacterium linens. Appl.Environ. Microbiol., 70, 7348-7354.

Dias, B., and Weimer, B. (1998) Purification and characterization of L-methioninase $\gamma$ lyase from Brevibacterium linens BL2. Appl. Environ. Microbiol., 64, 3327-3331.

El-Sayed, A.S.A. (2009) L-Methioninase production by Aspergillus flavipes under solid state fermentation. J. Basic Microbiol., 49, 331-341.

El-Sayed, A.S.A. (2011) Purification and characterization of new L-methioninase from solid culture of Aspergillus flavipes. J. Microbiol., 49, 130-140.

Ghareib, M. and Abu-Tahon, M. (2013) Purification and characterization of alkaline protease from Penicillium chrysogenum after solid-state fermentation. Egypt. J. Bot., 53(1), 181-194.

Hoffman, R.M. (1984) Altered methionine metabolism, DNA methylation, and oncogene expression in carcinogenesis: A review and synthesis. Biochem. Biophys. Acta., 738 49-87.

Kantardjieff, K.A. and Rupp, B. (2004) Protein isoelectric point as a predictor for increased crystallization screening efficiency. Bioinform., 20, 2162-2168.

Kreis, W. and Hession, C. (1973) Isolation and purification of L-Methionine- $\alpha$ deamino- $\gamma$-mercapto-methane-Lyase (L-Methioninase) from Clostridium sporogenes Cancer Res., 33, 1862-1865.

Krishnaveni, R., Rathod, V., Thakur, m.S. and Neelgund, Y.F. (2009) Transformation of L-tyrosine to L-Dopa by a novel fungus, Acremonium rutilum, under submerged fermentation. Curr. Microbiol., 58, 122-128.

Kudou, D., Misaki, S., Yamashita, M., Tamura, T., Takakura, T., Yoshioka, T. ans Yagi, S. (2007) Structure of the antitumor enzyme L-methionine $\gamma$-lyase from Pseudomonas putida at $1.8^{\circ}$ A resolution. J. Biochem., 141, 535-544.

Laemmli, U.K. (1970) Cleavage of structural proteins during the assembly of the head of bacteriophage T4. Nature, 227, 680-685.

Lineweaver H, Burk D (1934) The determination of enzyme dissociation constant J. Am. Chem. Soc., 56, 658-666.

Lockwood B.C. and Coombs G.H. (1991) Purification and characterization of methionine $\gamma$-lyase from Trichomonas vaginalis. Biochem. J., 279, 675-682.

Lowry O.H., Rosebrough N.J., Farr A.L. and Randall R.J. (1951) Protein measurements with the Folin phenol reagent. J. Biol. Chem., 93, 265-275.

Egypt. J. Bot., Vol. 56, No. 3 (2016) 
Manukhov, I., Mamaeva, D.V., Rastorguev, S.M., Faleev, N.G., Morozova, E.A., Demidkina, T.V. and Zavilgelsky, G.B. (2005) A gene encoding L-methionine $\gamma$ lyase is present in Enterobacteriaceae family genomes: Identification and characterization of Citrobacter freundii L-methionine $\gamma$-lyase. J. Bacteriol., 187, 3889-3893.

Martinez-Cuesta, M.C., Pelaez, M.C., Eagles, J., Gasson, M.J., Requena, T. and Hanniffy, S.B. (2006) YtjE from Lactococcus lactis IL1403 is a C-S lyase with $\alpha, \gamma$ elimination activity toward methionine. Appl. Environ. Microbiol., 72, 4878-4884.

Mecham, J.O., Rowitch, D., Wallace, C.D., Stern, P.H. and Hoffman, R.M. (1983) The metabolic defect of methionine dependence occurs frequently in human tumor cell lines. Biochem. Biophys.Res. Comm., 117, 429-434.

Miki, K., Al-Refaie, W., Xu, M., Jiang, P., Tan, Y., Bouvet, M. and Zhao, M. (2000) Methioninase gene therapy of human cancer cells is synergistic with recombinant methioninase treatment. Cancer Res., 60, 2696-2702.

Nakayama, T., Esaki, N., Lee, W.J., Tanaka, I., Tanaka, H., and Soda, K. (1984) Purification and properties of L-methioninase $\gamma$-lyase from Aeromonas sp. Agric. Biol. Chem., 48, 2367-2369.

Rebeille, F., Jabrin, S., Bligny, R., Loizeau, K., Gambonnet, B., Van Wilder, V., Douce, R. and Ravanel, S. (2006) Methionine catabolism in Arabidopsis cells is initiated by a gamma-cleavage process and leads to S-methylcysteine and isoleucine synthese. Proc. Natl. Acad. Sci. USA, 103, 15687-15692.

Ruiz-Herrera, J. and Starkey, R.L. (1969) Dissimilation of methionine by fungi. $J$. Bacteriol., 99, 544-551.

Sato, D., Yamagata, W., Harada, S., and Nozaki. T. (2008) Kinetic characterization of methionine $\gamma$-lyase from the enteric protozoan parasite Entamoemba histoytica against physiological substrates and trifluoromethionine, a promising lead compound against amoebiasis. FEBS J., 275, 548-560.

Secades, P. and Guijarro, J.A. (2001) Purification and characterization of a psychrophilic calcium-induced growth-phase-dependent metal-loprotease from fish pathogen Flavbacterium psychrophilum. App. Environ. Microbiol., 67, 2436-2444.

Selim, M.H., Karm Eldin, E.Z., Saad, M.M., Mostafa, E.E., Shetia, Y.H., and Anise, A.H.A. (2015) Purification, characterization of L-methioninase from Candida tropicalis, and its application as an anticancer. Biotechnol. Res. International, ID 173140, 10 pages.

Takakura, T., Ito, T., Yagi, S., Notsu, Y, Itakura, T., Nakamura, T., Inagaki, K., Esaki, N., Hoffman, R.M., and Takimoto, A. (2006) High-level expression and bulk crystallization of recombinant L-methioninase $\gamma$-lyase, an anticancer agent. Appl. Micrbial. Biotechnol., 70, 183-192.

Takakura, T., Mitsushima, K., Yagi, S., Inagaki, K., Tanaka, H., Esaki, N., Soda, K. and Takimoto, A. (2004) assay method for antitumor L-methionine $\gamma$-lyase:

Egypt. J. Bot., Vol. 56, No. 3 (2016) 
comprehensive kinetic analysis of complex reaction with L-methionine. Annal. Biochem., 327, 233-240.

Tan, Y., Sun, X., Xu, M., An, Z., Tan, X., Han, Q., Miljkovic, D.A., Yang, M., and Hoffaman, R.M. (1998) Polyethylene glycol conjugation of recombinant methioninase for cancer therapy protein. Expr. Purif., 12, 45-52.

Tanaka, H., Esaki, N. and Soda, K. (1977) Properties of L-methionine $\gamma$-lyase from Pseudomonas ovalis. Biochem., 16, 100-106.

Tanaka, H., N. Esaki, N. and Soda, K. (1985) A versatile bacterial enzyme:Methionine $\gamma$-lyase. Enz. Microb. Technol., 7, 530-536.

Thompson J.F. and Morrison G.R. (1951) Determination of organic nitrogen: control of variables in the use of Nessler's reagent. Anal. Chem., 23, 1153-1157.

Tokoro, M., Asai, T., Kobayashi, S., Takeuchi, T. and Nozaki, T. (2003) Identification and characterization of two isoenzymes of methionine $\gamma$-lyase from Entamoeba histolytica. J. Biol. Chem., 278, 42717-42727.

Yamamoto, N., Gupta, A., Xu, M., Miki, K., Tsugimoto, Y., Tsuchiya, H., Tomita, K., Mossa, A.R. and Hoffman, A.R. (2003) Methioninase gene therapy with selenomethionine induces apoptosis in bcl-2-overproducing lung cancer cells. Cancer Gene Therp., 10, 445-450.

(Received 30/5/2016;

Accepted 26/6/2016) 


\title{
تنقية وتوصيف إنزيم إل- ميثيونينيز القلوى الجديد فى مزارع \\ الحالة الصلبة لفطر اسبرجلس استس 1051 AUMC
}

\author{
ملاحت أحمد أبو طاحون و جوريج سعد إسحاق إنقات

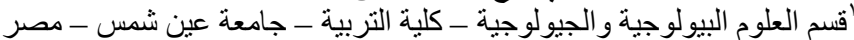 \\ ترجع أهمية إنزيم إل- ميثيونينيز كونه أحد الإنزيمات المستخدمة فى علاج الأورام

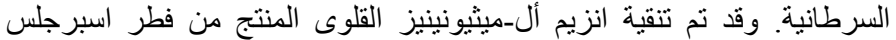

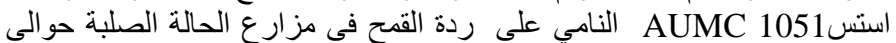

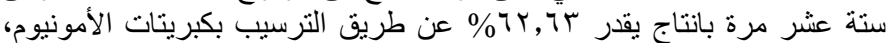

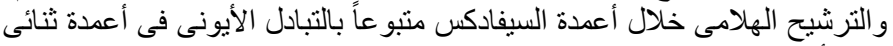

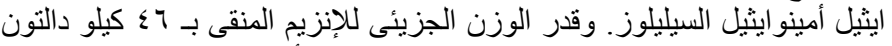

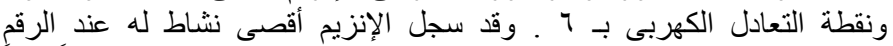

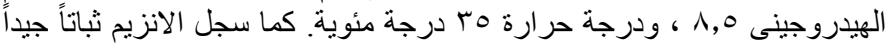

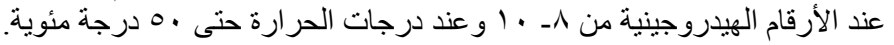

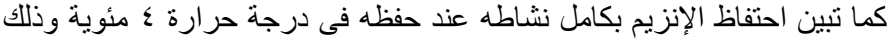

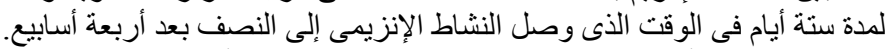

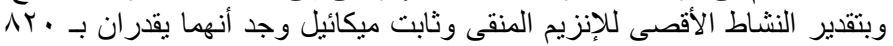

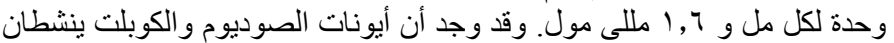

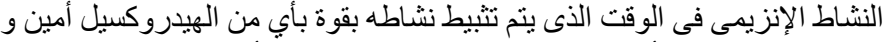

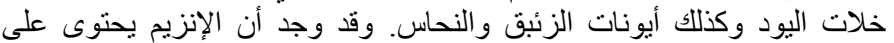 \\ مجمو عة سلفهيدريل فى موقعه النشط.
}

